\title{
Floristic Account of the Asclepiadaceous Species from the Flora of Dera Ismail Khan District, KPK, Pakistan
}

\author{
Sarfaraz Khan Marwat ${ }^{1}$, Mir Ajab Khan ${ }^{2}$, Mushtaq Ahmad ${ }^{2}$, Muhammad Zafar ${ }^{2}$, Khalid Usman ${ }^{3}$ \\ ${ }^{1}$ University Wensam College, Gomal University, Dera Ismail Khan, Pakistan; ${ }^{2}$ Department of Plant Sciences, Quaid-i-Azam Univer- \\ sity, Islamabad, Pakistan; ${ }^{3}$ Faculty of Agriculture, Gomal University, Dera Ismail Khan, Pakistan. \\ Email:skhan.marwat@gmail.com
}

Received June $4^{\text {th }}$, 2011; revised July $1^{\text {st }}, 2011$; accepted July $15^{\text {th }}, 2011$

\begin{abstract}
In the present study an account is given of an investigation based on the results of the floristic research work conducted between 2005 and 2007 in Dera Ismail Khan District, north western Pakistan. The area was surveyed and 8 Asclepiadaceous plant species were collected. These plant species are Calotropis procera (Aiton) W. T. Aiton. Caralluma edulis (Edgew.) Benth., Leptadenia pyrotecnica (Forssk.) Decne., Oxystelma esculentum (L. f.) R. Br., Pentatropis nivalis (J. F. Gmel.) D. V. Field \& J. R. I. Wood, Pergularia daemia (Forssk.) Blatt.\& McCann., Periploca aphylla Decne. and Stapelia gigantea N.E.Br. The study showed that five plants were used ethnobotanically in the area. All the plants were deposited as voucher specimens in the Department of plant sciences, Quaid-i-Azam University, Islamabad, for future references. Complete macro \& microscopic detailed morphological features of the species have been discussed. Taxonomic key was developed to differentiate closely related taxa.
\end{abstract}

Keywords: Taxonomic Account; Asclepiadaceae; Dera Ismail Khan; Pakistan

\section{Introduction}

Dera Ismail Khan (D. I. Khan) is located in the northwestern Pakistan (Figure A1) and has an elevation of 173 meters above sea level. It has a total geographical land mass of 0.896 million hectares (2.214 million acres) out of which $33 \%$ is cultivated [1]. The climate is continental with marked temperature fluctuations both seasonal and diurnal, with significant aridity. January is the coldest month of the year and July the hottest. The mean maximum and minimum temperatures during winter are $20.3^{\circ} \mathrm{C}$ and $4.2^{\circ} \mathrm{C}$ respectively, compared to $42^{\circ} \mathrm{C}$ and $27^{\circ} \mathrm{C}$ during summer. Average annual rainfall is $259 \mathrm{~mm}$ [2].

The family Asclepiadaceae forms a well represented group of Angiosperms. But it has received relatively meager attention. No efforts have previously been made in connection with the Taxonomy of the family Asclepiadaceae from the flora of Dera Ismail Khan District. The present study was conducted during 2005-2007. This study which highlights the taxonomy and diversity of the family Asclepiadaceae available within the area forms a small part of the entire flora.

Asclepiadaceae is a large family consisting about 175 180 genera and 22,000 species. Of these 23 genera and 41 species occur in Pakistan [3,4] and in Dera Ismail Khan District it is represented by eight genera and eight species. Out these, two species are herbs (Caralluma edulis and Stapelia gigantea), three species are climbers (Oxystelma esculentum, Pentatropis nivalis, Pergularia daemia and three are shrubs (Calotropis procera, Leptadenia pyrotecnica and Periploca aphylla).

All species have been critically examined and detailed taxonomic information such as recently accepted botanical name with common synonyms, vernacular names, description, ecology, uses and reference have been provided. Plants were identified with the help of available literature [3-5] and by comparing with the already identified plant specimens of the herbarium, Quaid-i-Azam University, Islamabad. After correct identification, the plants were deposited as voucher specimens in the Department of plant sciences, Quaid-i-Azam University, Islamabad, for future references. Complete macro \& microscopic detailed morphological features of the species have been discussed also summarized in Table A1. Taxonomic key was developed to differentiate closely related taxa.

\section{Key to the Species}

1a. Filaments usually free; pollen masses granular--------7. Periploca aphylla

1b. Filaments connate into a tube; pollen masses waxy--2

2a. Plants with erect stems------------------------------3

2b. Plants climbers with twining stems----------------------6

3a. Stems fleshy, 4-angled, ----------------------------------4 
3b. Stem not fleshy, terete, 60 - $210 \mathrm{~cm}$ high--------------5

4a. Corolla 6 - 7 mm long, lobes ovate-lanceolate, acute--

-2. Caralluma edulice

4b. Corolla 11 - 12 cm long------------8. Stapelia gigantea

5a. Leaves broad, upto $10 \mathrm{~cm}$ wide; flowers waxy white, with purple-tipped (inside) petals; follicles inflated about $5 \mathrm{~cm}$ broad ---------------1. Calotropis procera

5b. Leaves linear, about $3 \mathrm{~mm}$ broad; flowers yellowish green; follicles lanceolate, about $6 \mathrm{~mm}$ broad----------

-3. Leptadenia pyrotecnica

6a. Leaves broadly ovate, deeply cordate; follicles softly spiney-------------------6. Pergularia daemia

6b. Leaves ovate to linear; follicles smooth----------------7

7a. Flowers greenish; corolla divided almost to the base-5. Pentatropis nivalis

7b. Flowers pale-rose with purple veins; corolla divided half way down-

4. Oxystelma esculentum

\section{Enumeration of the Species}

\subsection{Calotropis procera}

(Aiton) W. T. Aiton, Hortus Kew. ed. 2. 2: 78. 1811.

Ali in Notes RBG Edinb. 38(2):287-290. 1980. (Figure 1).

Basionym: Asclepias procera Aiton, Hort. Kew. 1: 305. 1789.

An erect tall shrub up to $3.5 \mathrm{~m}$ high, having milky latex, much branched from the base covered with soft white tomentum. Leaves $5-13 \mathrm{~cm}$. long and up to $10 \mathrm{~cm}$ wide, broadly ovate-oblong, elliptic or obovate, sub sessile, opposite, thick. Flowers showy, arranged in umbelliform multiparous cymes, about $2 \mathrm{~cm}$. in diam., waxy whit; "corona" scales about $6 \mathrm{~mm}$ long, equaling or exceeding the staminal column; sepals 5 , glandular within; corolla broadly lobed, purple tipped inside. Follicles fruit grey-green, inflated, 8 to $12 \mathrm{~cm}$ long and 5 - $7 \mathrm{~cm}$ broad, ellipsoid or ovoid, usually somewhat recurved, contain-

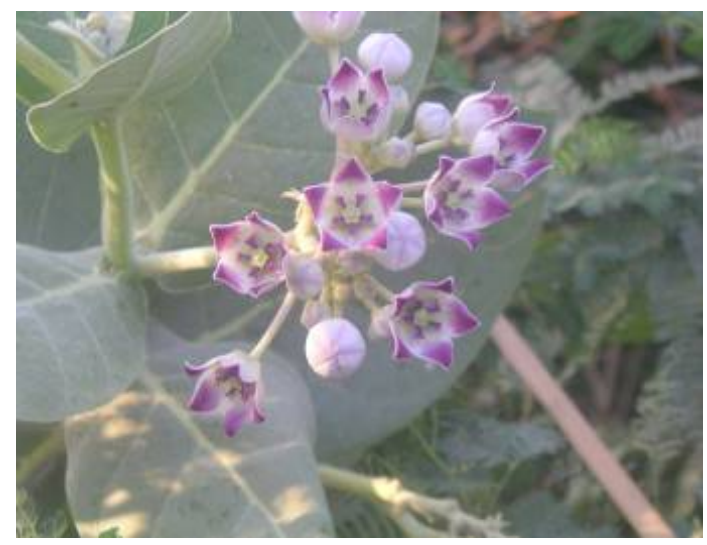

Figure 1. Calotropis procera (Aiton) W. T. Aiton: vegetative and floral parts. Source: [Photo by Author]. ing numerous seeds with tufts of long silky hairs at one end.

Flowering and Fruiting: Throughout the year.

Distribution: Cultivated for medicine in S Guangdong, Guangxi, S Yunnan [Afghanistan, India, Myanmar, Nepal, Pakistan, Thailand, Vietnam; Africa, SW Asia, introduced to Australia and Central and South America].

Uses: The ethno-medico-botanical study on the plant Calotropis procera has revealed the enormous diversity of its medicinal uses and popular use of the plant C. procera for a wide range of common ailments like fevers, rheumatism, indigestion, cough, cold, eczema, asthma, elephantiasis, nausea, vomiting and diarrhea. Either the whole plant or a plant part used singly or mixed with other plant materials to enhance the efficacy [6]. Local people use its latex (milk) for the treatment of snakebite and for the removal of pierced (pricked) thorn or spine from the affected area of the body. It is also applied to the affected part of the body where blood has coagulated. 5 - 8 flowers are taken in, at a time,with water for the treatment of abdominal pain [7]. The bark and leaves are used for the treatment of leprosy and asthma, respectively [8].

Specimen examined: Daman: Khuti, 3. 11.2007, SK Marwat, 233 (ISL).

\subsection{Caralluma edulis}

(Edgew.) Benth. in Gen. Pl., ii: 782 (1876). (Figures 2(a)(f)).

Basionym: Boucerosia edulis Edgew. in J. Lin. Soc. Bot., vi: 205, t.1. (1862).

Synonym: Boucerosia stocksiana Boiss., Fl. Or., iv: 64 (1879).

Succulent perennial erect, herb, $10-45 \mathrm{~cm}$ tall, with sub terete stem having 4 grooves, almost leafless; leaves when present linear or ovoid-lanceolat, fleshy caducous, 6 - $12 \mathrm{~mm}$ long. Flowers 1 - 4 together, about $6 \mathrm{~mm}$ long, purple and glabrous inside; pedicels 3.5 - $13 \mathrm{~mm}$ long. Sepals 5, c. $2.5 \mathrm{~mm}$, glabrous, ovate, acute. Corolla rotate campanulate, purple inside, c. 6 - $7 \mathrm{~mm}$ long, lobes ovate-lanceolate, acute; "corona" double, staminal, the outer cupular, adnate to the inner corona-lobes at their base, 5-lobed, the lobes 2-cuspidate; staminal column short; anthers without appendages; pollinia present. Follicles narrowly fusiform, smooth; seeds comose.

Flowering and Fruiting: Septembers

Distribution in World: India, Pakistan.

Uses: It has cooling, alterative, anthelmintic effects; very effective in blood diseases. It is cooked at homes as vegetable and is considered nutritive and used for rheumatism and blood purification. Its juice is used for diabetes [9-11].

Specimen examined: Khysore Range: Aghzan Khel, 13. 

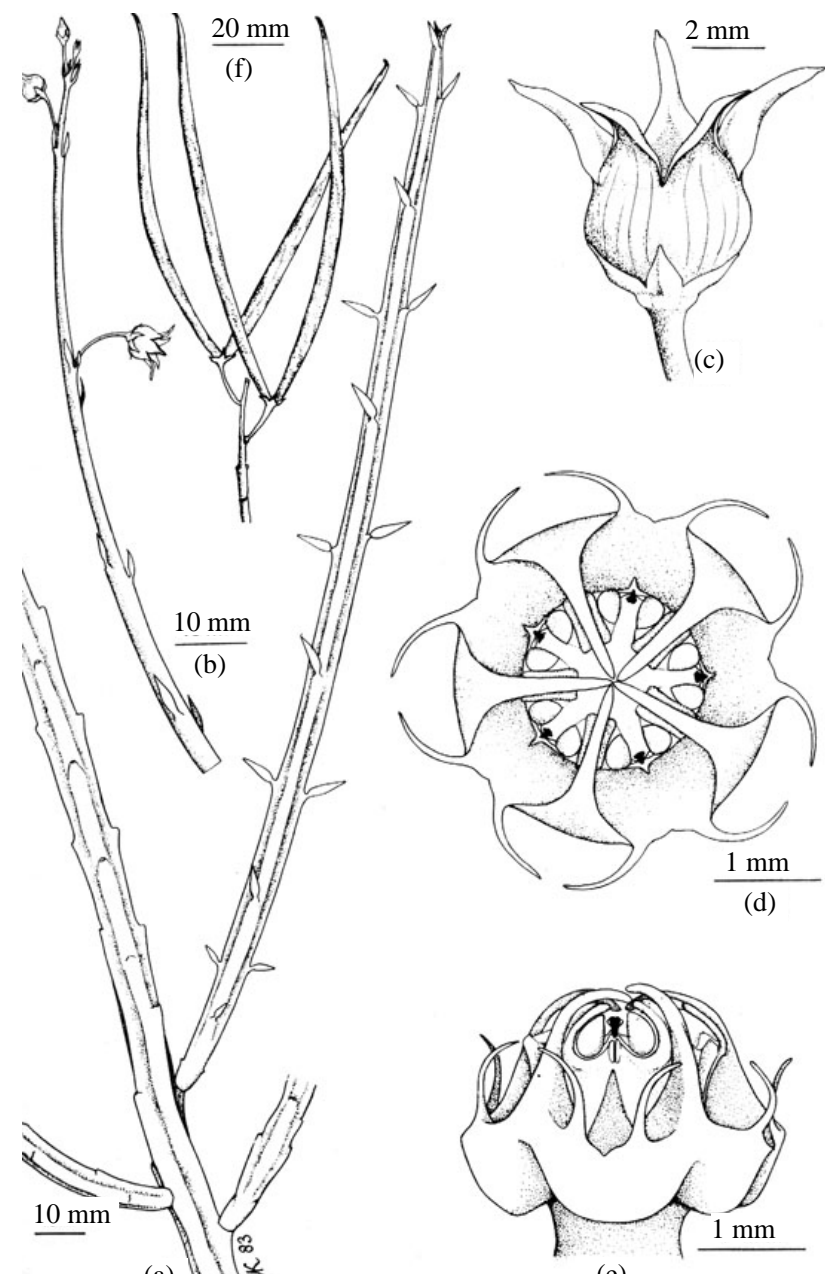

(a) 11 \%

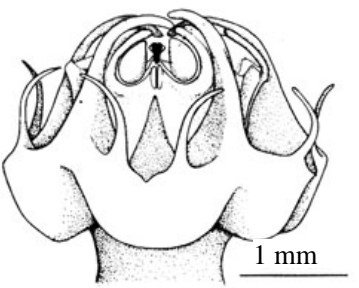

(e)

Figure 2. Caralluma edulis: (a) Vegetative branches; (b) Branch of flowering branch; (c) Flower; (d) Corona and gynostegium (top view); (e) Corona and gynostegium (lateral view); (f) Portion of fruiting branch. Source: [4].

\subsection{7, SK Marwat, 256 (ISL).}

\subsection{Leptadenia pyrotecnica}

(Forssk.) Decne. in Ann. Sc. Nat. 11(ix): 262(1838). (Figures 3(a)-(e)).

Basionym: Synanchum pyrotecnicum Forssk., Fl. Aegypt.-Arab.,53(1775).

Synonym: Leptadenia spartium Wight, Contr., 48 (1834).

An erect, much branched, rush like, often leafless green shrub, up to $180 \mathrm{~cm}$ or more high; branches green, tapering. Leaves when present more or less linear, 2 - 5 cm long and about $3 \mathrm{~mm}$ broad, sessile. Flowers yellowish in short pubescent, lateral cymes; corolla deeply divided, rotate; “corona” double. Follicles 7 - 12 cm long, $6 \mathrm{~mm}$ broad, lanceolate, beaked; seeds comose.

Flowering and Fruiting: July - November.

Distribution: India, Pakistan, Arabia and Egypt.
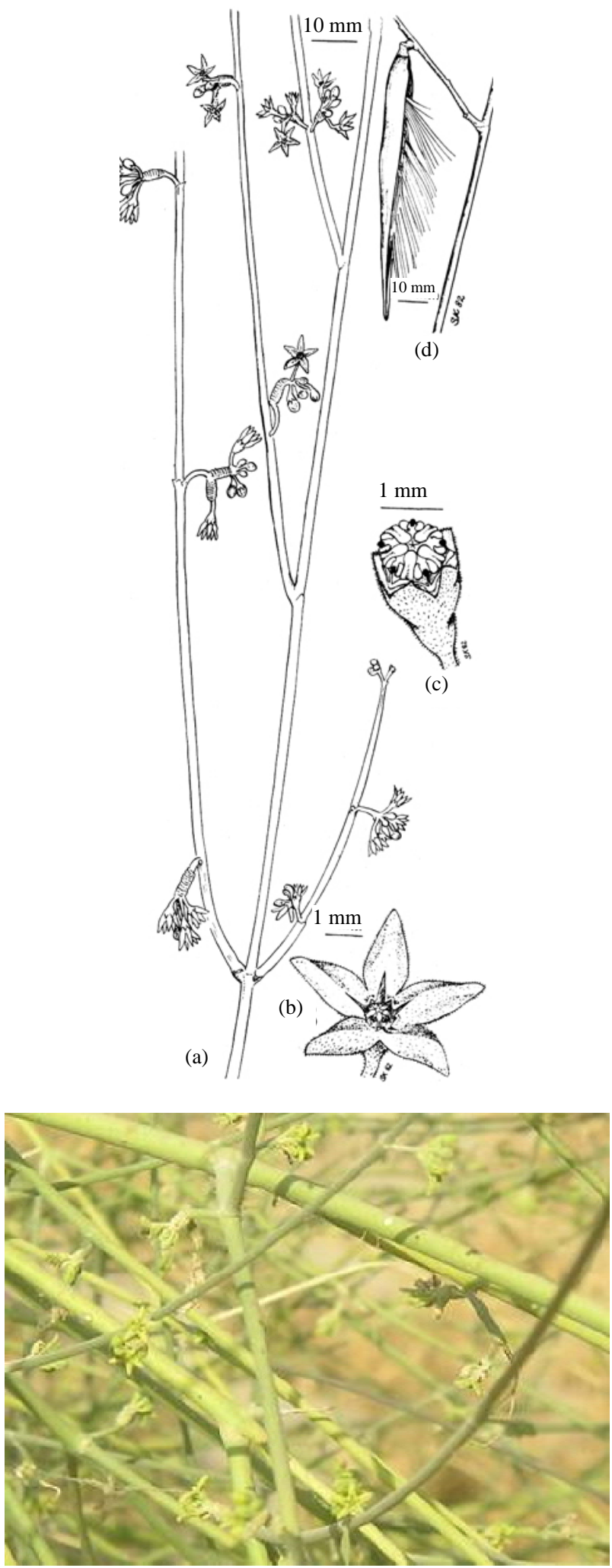

(e)

Figure 3. Leptadenia pyrotechnica: (a) Flowering branch; (b) Flower; (c) Calyx with gynostegium and staminal corona; (d) Dehisced fruit. Source: [4]. (e) Vegetative branches and inflorescenc. Source: [Photo by author]. 
Uses: The leaves and bark of the plant are used in folk medicine to prepare antispasmodic, anti-inflammatory, antihistaminic, anti-bacterial diuretic, urolith expulsion, expectorant, gout, and rheumatism remedies [12]. Latxe of branches to is applied tumours and swellings. The fresh plant is browsed by animals. The dried plant is commonly used as fuel.

Specimen examined: Dera Ismail Khan, 3. 7. 2007, S K Marwat, 82 (ISL).

Taxonomic note: This taxon closely resembles Periploca aphylla Decne. in general appearance but differs in having yellowish sap, yellowish green flowers and filaments connate into a tube. In Periploca aphylla Decne. the sap is milky, the flowers are greenish outside and dark-purple within and the filaments are usually free.

\subsection{Oxystelma esculentum}

(L.f.) R. Br. in Mem, Wern. Soc., i: 40(1809). (Figures 4 (a)-(d)).

Basionym: Periploca esculenta L. f., Supply. 168 (1781).

Synonym: Sarcostemma esculentum (L. f.) R. W. Holm.

Plants climbers to at least $4 \mathrm{~m}$, glabrous except for flowers. Petiole $1-1.5 \mathrm{~cm}$; leafblade linear or linearlanceolate, $6-11 \times 0.7-2 \mathrm{~cm}$, membranous, base rounded; lateral veins 9 - 12 pairs, marginal vein present. Inflorescences longer than leaves, (1- or) 2-4-flowered. Flower buds 8 - $9 \mathrm{~mm}$. Sepals ovate-lanceolate, ca. $3.5 \times$ $1 \mathrm{~mm}$. Corolla white with purple veins or blotches, 2 - 3 $\mathrm{cm}$ in diam., limb 1.5 - $2 \mathrm{~cm}$; lobes triangular, $1-1.5 \mathrm{~cm}$, densely ciliate. Outer corona densely pubescent. Pollinia ca. $1.5 \mathrm{~mm}$. Ovaries glabrous. Follicles lanceolate in outline, ca. $5 \times 1.5 \mathrm{~cm}$, apex subacute. Seeds ovate, ca. $2 \times$ $1.5 \mathrm{~mm}$; coma 1.5 - $2 \mathrm{~cm}$.

Flowering and Fruiting: July - September.

Distribution: China, Bangladesh, Cambodia, India, Indonesia, Laos, Malaysia, Myanmar, Nepal, Pakistan, Sri Lanka, Thailand, Vietnam; NE Africa, SWAsia.

Uses: The fruit is eaten and the plant is reputed to have medicinal properties [4]. The plant is used as anti-ulcer, laxative, diuretic, antiseptic, depurative, anthelmintic, aphrodisiac, hepatoprotective and useful in leucoderma and bronchitis. Decoction of plant is used in ulcer, sorethroat and itches. Milky juice is used as galactogogue, anti-periodic, anti-ulcer and as a vulnerary. Leaves are used as antiperiodic. Its root is prescribed in jaundice. Fruit is bitter, tonic, expectorant and anthelmintic. Fruit juice is used in muscle pain, gonorrhoea, cough and leucoderma, and given to children as astringent [13]. Decoctions of all parts are used against cancer, menoxenia, and traumatic injury [8].
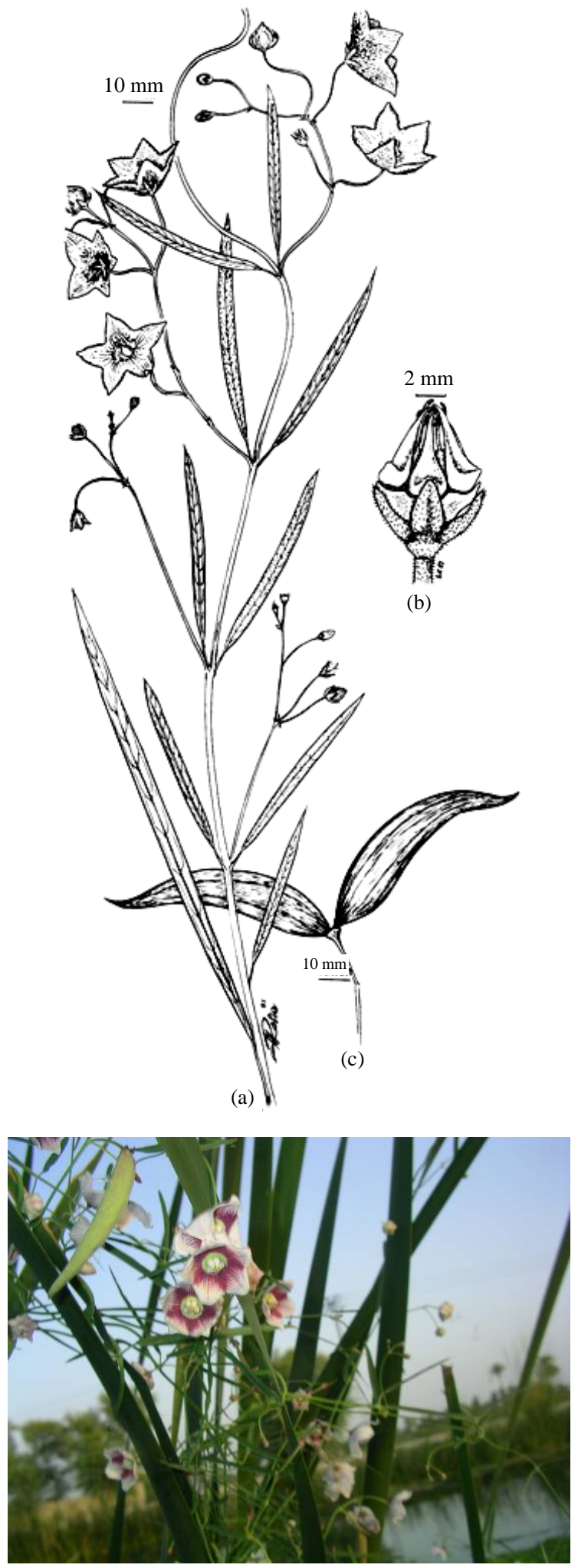

(d)

Figure 4. Oxystelma esculentum (L. f.) R. Br.: (a) Flowering twig; (b) Corona and gynostegium; (c) Fruit; Source: [4]. (d) Vegetative branches, flowers and fruit of Oxystelma esculentum. Source: [Photo by author]. 
Specimen examined: Paharpur: Sewerage canal, 5.7. 2007, S K Marwat, 131, (ISL).

\subsection{Pentatropis nivalis}

(J. F. Gmel.) D. V. Field \& J. R. I. Wood, Kew Bull. 38 (2):215 (1983). (Figures 5(a)-(f)).
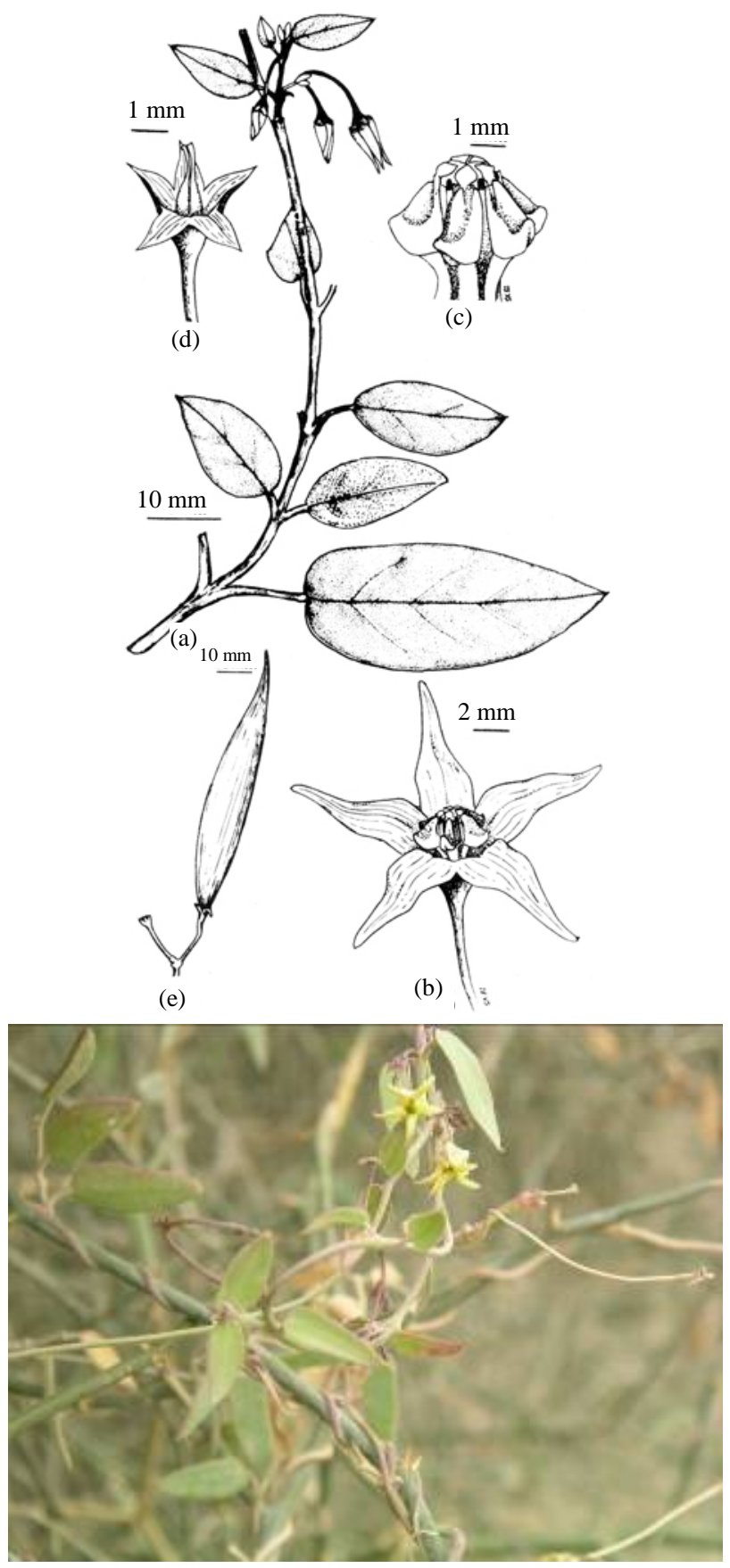

(f)

Figure 5. Pentatropis spiralis: (a) Flowering twig; (b) Flower; (c) Corona and gynostegium; (d) Calyx and ovaries; (e) Fruit Source: [4]. (f) Vegetative branches and flowers. Source: [Photo by author].
Basionym: Asclepias nivalis J. F. Gmel, (1791).

Perennial twiner, nearly glabrous, with tuberous roots. Leaves very variable, ovate to linear, $2-4 \mathrm{~cm}$ long and 5 - $20 \mathrm{~mm}$. broad, more or less thick, glabrous, mucronate. Flowers greenish, c. $12 \mathrm{~mm}$ in diam., in 3 - 6 flowered cymes; corolla divided almost to the base, with narrow elongate lobes; "corona" scales laterally compressed, vertically adnate to the backs of the anthers, with free tips and spurred bases, staminal tube short. Follicles 5 - 8 $\mathrm{cm}$ long, c. $1 \mathrm{~cm}$ broad, lanceolate tapering into a beak, smooth, glabrous; seeds with long hairs.

Flowering and Fruiting: July - November.

Distribution in World: India, Pakistan, Afghanistan, Arabia Tropical Africa.

Specimen examined: Daman: Khuti, 3.9.2007, S K Marwat, 347 (ISL).

Taxonomic note: This species resembles Oxystelma esculentum (L. f.) R. Br. in general appearance but differs in possessing ovate to linear, $2-4 \mathrm{~cm} \times 0.5-20 \mathrm{~cm}$ leaves and greenish flowers. In Oxystelma esculentum (L. f.) $\mathrm{R}$. $\mathrm{Br}$. the leaves are linear-lanceolate, 6 - $11 \times 0.7$ - 2 $\mathrm{cm}$. and pale-rose with purple veins flowers.

It is shown that Forsskl's Asclepias spiralis has been misinterpreted, and the plant long known as Pentatropis spiralis based on Forsskl's name must be known by the new combination Pentatropis nivalis [14].

Uses: The flowers are used medicinally and the tubers are reportedly, eaten [4].

\subsection{Pergularia daemia}

(Forssk.) Blatt. \& McCann in Journ. Bomb. Nat. Hist. Soc. 36:528(1933). (Figures 6(a)-(d)).

Basionym: Asclepias daemia Forssk. Fl. Aegypt-Arab., 51(1775).

Synonym: Cynanchum cordifolium Retz., Obs., 2:15 (1779-1781).

A climbing twiner, glabrous green, with milky juice. Leaves opposite, broadly ovate, deeply cordate acuminate, $2.5-10 \times 2-8 \mathrm{~cm}$, petiole long, auricles incurved and often meeting. Flowers in cymes on long axillary peduncles, 10 - $15 \mathrm{~mm}$ in diam., yellowish-green usually tinged with brownish or reddish base; corolla with broadly ovate spreading lobes; corona double. Follicles reflexed parallel, 5 - $8 \times 1.5 \mathrm{~cm}$ lanceolate, tapering towards the apex, echinate; seeds c. $7 \mathrm{~mm}$ long, ovate, pubescent, narrowly margined.

Flowering and Fruiting: May - July.

Distribution: Egypt, Ethiopia, Cameroon, Gambia, Ghana, Liberia, Nigeria, Senegal, Botswana, Namibia, South Africa, Swaziland; India; Pakistan; Sri Lanka, Myanmar, Malaysia.

Uses: Root powder mixed in water is given for helminthiasis [15]. 

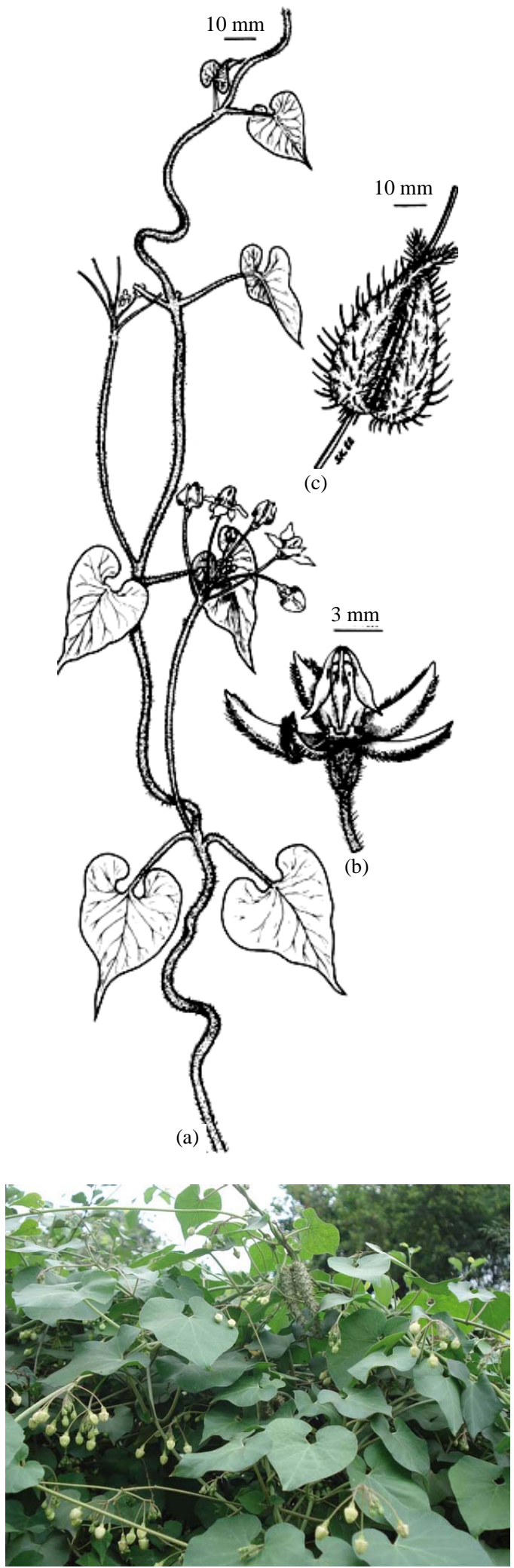

(d)

Figure 6. Pergularia daemia: (a) Flowering branch; (b) Flower; (c) Fruit. Source: [4]. Pentatropis spiralis: (d) vegetative branches, flowers and fruit. Source: [Photo by author].
Specimen examined: Paniala, 25.6.2007, SK Marwat, 238 (ISL).

\subsection{Periploca aphylla}

Decne. in Jacquemont,Voy. Bot., 109, t. 116(1844). (Figures 7(a)-(e)).
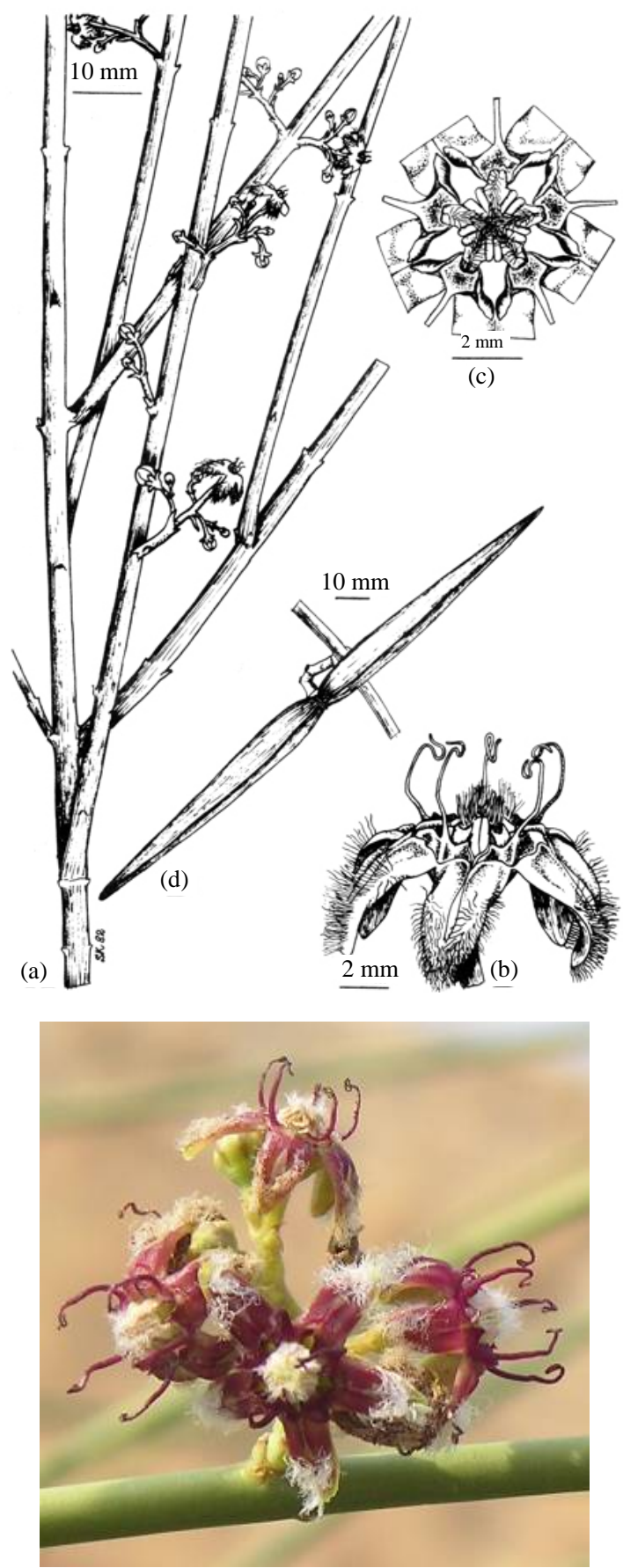

(e)

Figure 7. Periploca aphylla: (a) Flowering twig; (b) Flower; (c) Center of flower (top view); (d) Fruit. Source: [4]. (e) Flowers of Periploca aphylla. Source: [Photo by author]. 
An erect milky shrub branched, leafless, smooth or pubescent at tips Leaves when present minute, c. $6 \mathrm{~mm}$ long, ovate oblong, opposite, thick, acute and nerveless. Flowers small in lax cyme, fragrant; sepals 5, glandular within; corolla greenish outside, dark-purple within, densely bearded inside; stamens within the corona, filament short, flat; follicles 7.5 - $10 \mathrm{~cm}$ long, c. $6 \mathrm{~mm}$ broad, widely divergent, rigid, woody; seeds comose.

Flowering and Fruiting: March - November.

Distributio: Rajputana, Pakistan, Afghanistan, Iran, to Egypt.

Uses: Half tea cup of fresh juice of P. aphylla is given twice a day to over come constipation. The ash is used as poultice for curing swollen joints and other body parts [16]. The plant decoction is used as purgative, while the milky juice is applied to tumors and swellings [17]. Roots are stimulant. It is used for constipation, urticaria and tumor [18].

Specimen examined: Paharpur: Bilot Sharif, 25.11. 2007, S K Marwat, 227 (ISL).

\subsection{Stapelia gigantea}

N. E. Br., Gard. Chron. London. t. 684. f. 112. (1877). (Figure 8).

Synonym: Stapelia nobilis N. E. Br. ex Hook. f., Bot. Mag. London 127:t. 7771. (1901).

Perennial herb. Stems erect or decumbent, $10-20 \mathrm{~cm}$ long, softly pubescent, clustering succulent, cylindrical, vertically deeply four-ridged (4-angled), bearing tubercles, number of tubercles per ridge 6 - 12. Each tubercle short lived and leaves a round scar on the ridge. The floral buds are very distinctive, large and inflated like a bladder, with the petals all joined together and extended forward into a lengthened, spirally twisted tip, $1-2$ in clusters near the base or middle of young branches, pedicels $4-5 \mathrm{~cm}$ long with gigantic flowers to $25 \mathrm{~cm}$ or

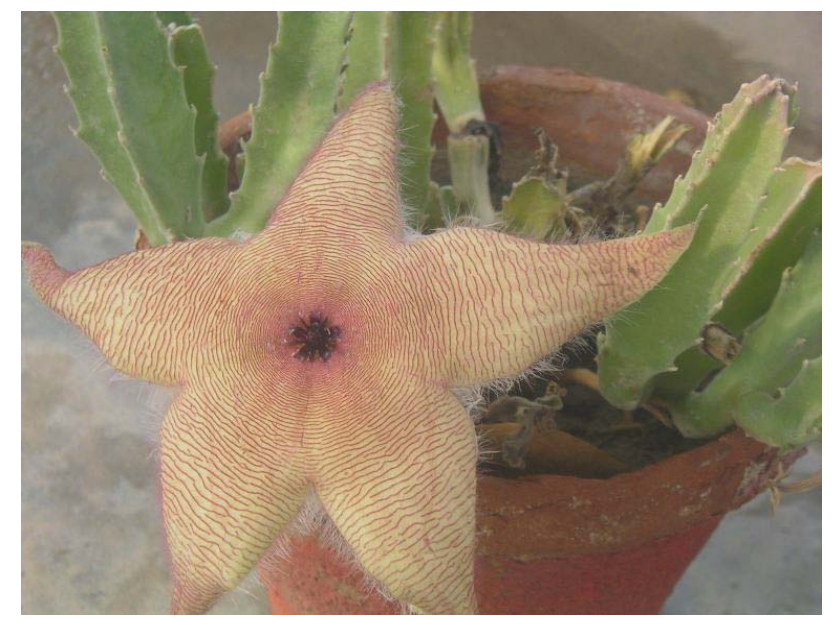

Figure 8. Stapelia gigantea: Vegetative parts and star shaped big flower. Source: [Photo by author]. more across. The flower is starfish-shaped, background on the margins, distance between two tubercles 5 - 20 $\mathrm{mm}$, bears a small leaf rudiment which may be up to 2 $\mathrm{mm}$ long, colour of the flower ranges from pale yellowish to cream. Calyx deeply 5 or 6-lobed, much smaller than the corolla, fused at the base, $8-10 \times 2-3 \mathrm{~mm}$, pointed. Corolla with five petals, divided about halfway into five lobes, $11-12 \mathrm{~cm}$ long, the lower surfaces of the petals are greenish, with longitudinal ridges tretching along their backs towards the tips, lobes 6 - 10 veined, margins of the lobes densely hairy, hairs 5 - $8 \mathrm{~mm}$ long, much longer than the central hairs. The upper surface of the flower is pale yellow with crimson transverse lines and purple hairs, foul smelling. The hairs are reddish to purplish and increase in length and density towards the centre of the flower. Corona purplish brown. The corona holds the pollen-packs of the flower, as well as the ovaries where the seeds develop. Fruit a pair of follicles 10 $20 \mathrm{~cm}$ long, containing numerous silky-tufted seeds.

Flowering and Fruiting: October - November.

Ecological condition: Cultivated in Gardens.

Distribution: Originated in South Africa, the Giant Carrion Flower is one of the most widely distributed carrion flower species. It is scattered throughout Zimbabwe and Mozambique and also Eastern Botswana. It has also been recorded in Zambia and Malawi. For Pakistan it is a new record and found in Dera Ismail Khan, Peshawar and Islamabad [10].

Specimen examined: Dera Ismail Khan: University WENSAM College, 08.9.2007, S K Marwat, 415 (ISL).

\section{REFERENCES}

[1] R. U. Khan, "Facts about AZRI," Pakistan Agricultural Research Council, Arid Zone Research Institute Ratta Kulachi, D. I. Khan, 2003, pp. 2-4.

[2] Anonymous, "District Census Report of Dera Ismail Khan,” Census Publication No. 50, Population Census Organization Statistic Division Government of Pakistan, Islamabad, 1998, pp. 1-2.

[3] R. R. Stewart, "An Annotated Catalogue of the Vascular Plants of West Pakistan and Kashmir,” In: E. Nasir and S. I. Ali, Eds., Flora of West Pakistan, Karachi, 1972, pp. 566-571.

[4] S. I. Ali, “Asclepiadaceae,” In: E. Nasir and S. I. Ali, Eds., Flora of Pakistan-Karachi, Vol. 150, 1983, pp. 1-165.

[5] S. K. H. Jafri, “The Flora of Karachi,” The Book Corporation, Karachi, 1966, pp. 248-257.

[6] R. Verma, G. P. Satsangi and J. N. Shrivastava, "EthnoMedicinal Profile of Different Plant Parts of Calotropis procera (Ait.) R. Br.,” Ethnobotanical Leaflets, Vol. 14, 2010, pp. 721-742.

[7] S. K. Marwat, M. A. Khan, M. Ahmad, M. Zafar and F. ur Rehman, "Ethnophytomedicines for Treatment of Various Diseases in D. I. Khan District," Sarhad Journal of 
Agriculture, Vol. 24, No. 2, 2008, pp. 293-303.

[8] B. Li, M. G. Gilbert and W. D. Stevens, "Asclepiadaceae,” In: W. Zhengyi, P. H. Raven and H. Deyuan, Eds., Flora of China, Vol. 16, 1994, pp. 189-202,

[9] A. Mahmood, A. Mahmood, H. Shaheen, R. A. Qureshi, Y. Sangi and S. A. Gilani, "Ethno Medicinal Survey of Plants from District Bhimber Azad Jammu and Kashmir, Pakistan,” Journal of Medicinal Plants Research, Vol. 5, No. 11, 2011, pp. 2348-2360.

[10] M. Ahmad, M. Zafar, M.A. Khan, Z. Ahmad, M. Lisa and M. Fayyaz, "The Diversity of Asclepiads on the Potwar Plateau of Pakistan,” The International Asclepiad Society, 2007, pp. 5-17.

[11] M. Ahmad, R. Qureshi, M. Arshad, M. A. Khan and M. Zafar, "Traditional Herbal Remedies Used for the Treatment of Diabtes from District Attock (Pakistan)," Pakistan Journal Botany, Vol. 41, No. 6, 2009, pp. 27772782.

[12] A. M. Y. Moustafa, A. I. Khodair and M. A. Saleh, "Isolation, Structural Elucidation of Flavonoid Constituents from Leptadenia Pyrotechnica and Evaluation of Their Toxicity and Antitumor Activity,” Pharmaceutical Biology, Vol. 47, No. 6, 2009, pp. 539-552. doi:10.1080/13880200902875065

[13] D. J. Pandya and I. S. Anand, “Anti-Ulcer Potential of Oxystelma esculentum," International Journal of Green Pharmacy, Vol. 5, No. 1, 2011, pp. 65-68.

\section{doi:10.4103/0973-8258.82101}

[14] D. V. Field and J. R. I. Wood, “A New Name for Pentatropis spiralis auctt., and the Resurrection of the Genus Blyttia (Asclepiadaceae)," Kew Bulletin, Vol. 38, No. 2, 1983, pp. 215-220. doi:10.2307/4108107

[15] J. L. Bapuji and S. V. Ratnam, "Traditional Uses of Some Medicinal Plants by tribals of Gangaraju Madugula Mandal of Visakhapatnam District, Andhra Pradesh," Ethnobotanical Leaflets, Vol. 13, 2009, pp. 388-398.

[16] L. Badshah and F. Hussain, "People Preferences and Use of Local Medicinal Flora in District Tank, Pakistan," Journal of Medicinal Plants Research, Vol. 5, No.1, 2011, pp. 22-29.

[17] W. Murad, A. Ahmad, S. A. Gilani and M. A. Khan, "Indigenous Knowledge and Folk Use of Medicinal Plants by the Tribal Communities of Hazar Nao Forest, Malakand District, North Pakistan,” Journal of Medicinal Plants Research, Vol. 5, No. 7, 2011, pp. 1072-1086.

[18] A. Mahmood, A. Mahmood and A. Tabassum, "Ethnobotanical Survey of, Plants from District Sialkot Pakistan," Journal of Applied Pharmacy, Vol. 2, No. 3, 2011, pp. 2012-2220.

[19] S. K. Marwat and M. A. Khan, "Stapelia gigantea N.E. Br. (Asclepiadaceae)—A New Angiospermic Record for Pakistan," American-Eurasian Journal of Agricultural \& Environmental Sciences, Vol. 6, No. 2, 2009, pp. 203-205. 


\section{Appendix}

Table A1. Distinguishing characters used for identification of Asclepiads of D. I. Khan district.

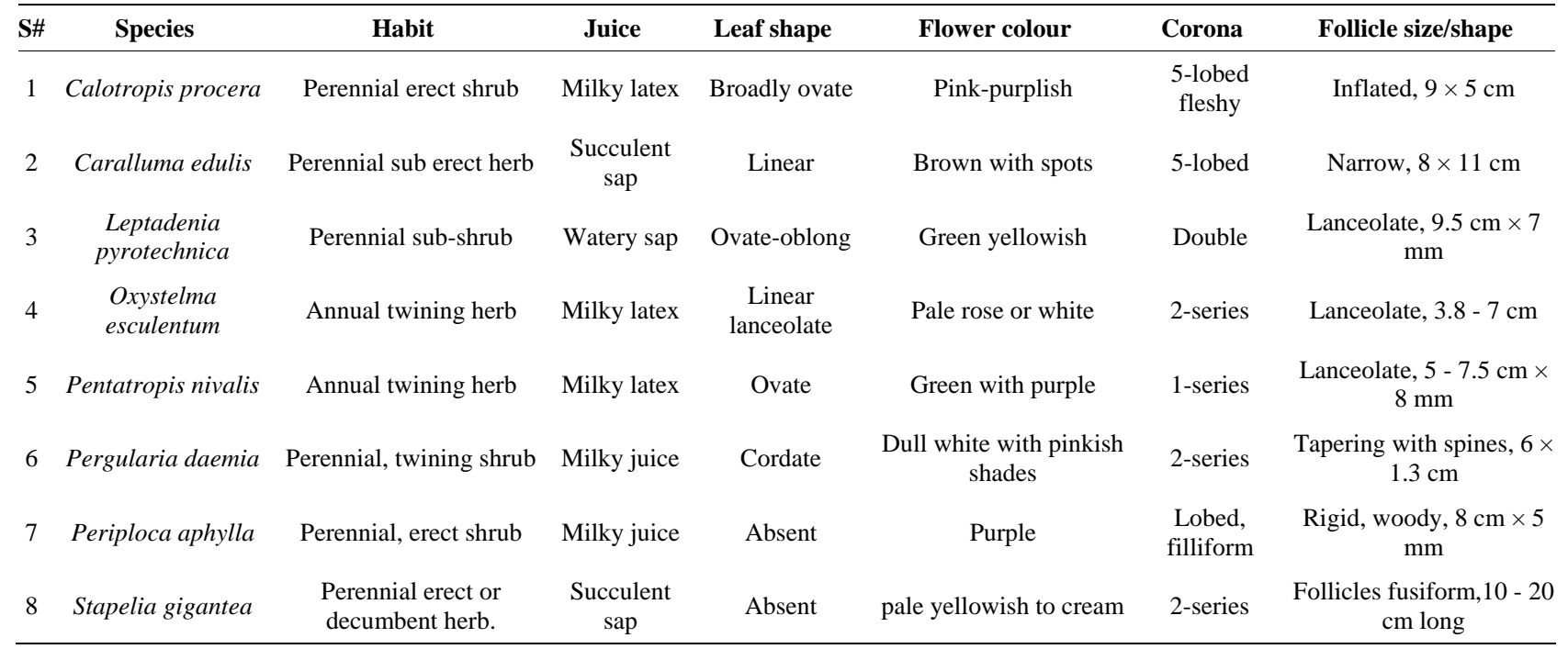

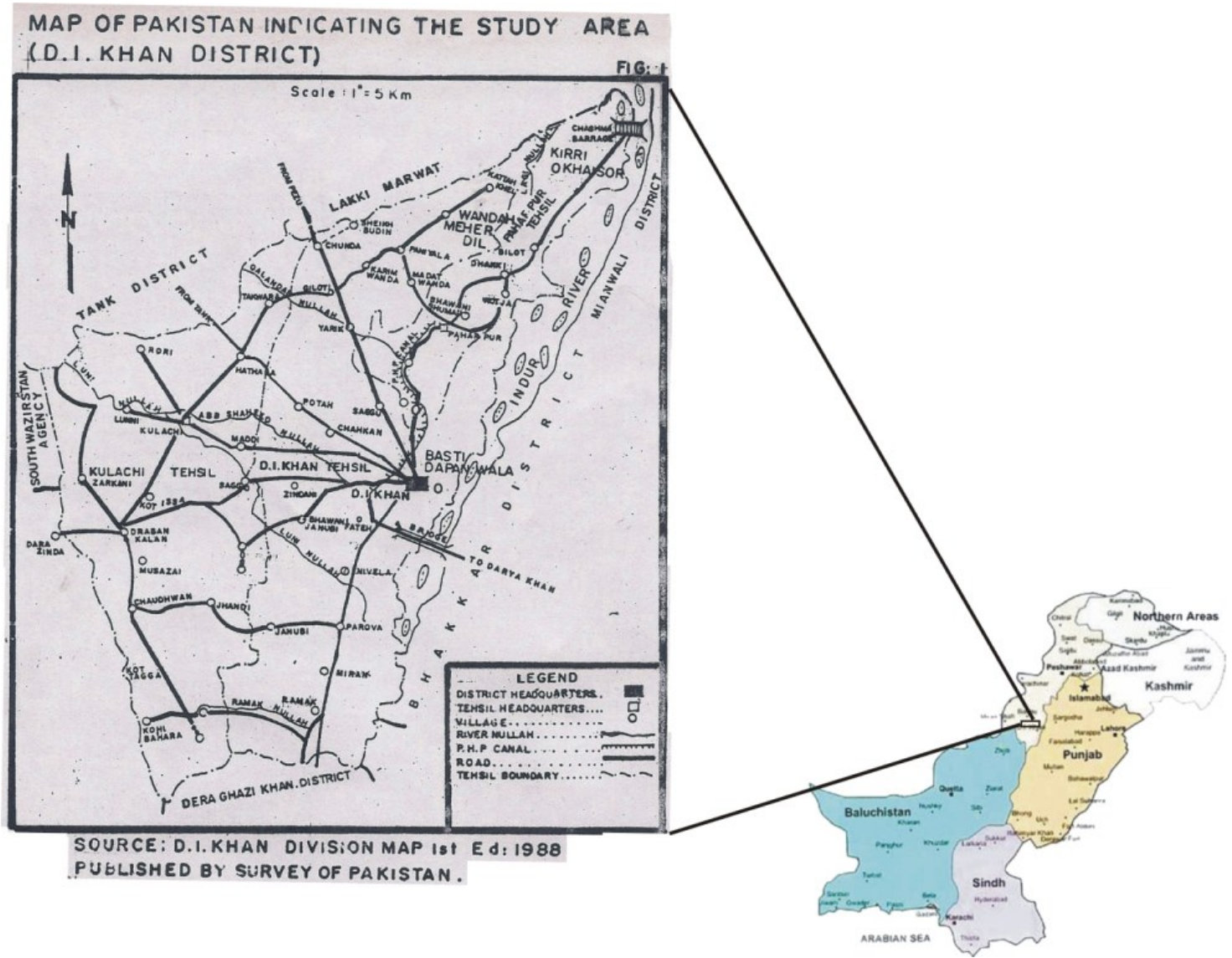

Figure A1. Geographic location of Dera Ismail Khan in Pakistan. 